\title{
NEUROGENIC MODULATION BY NEUROKININ-1 RECEPTOR ANTAGONIST, CP-96,345 TO INHIBIT RHEUMATOID ARTHRITIS DEVELOPMENT IN ADJUVANT INDUCED ARTHRITIS RAT MODEL
}

\author{
Yuyun Wirasasmita ${ }^{1}$, Mahardian Rahmadi ${ }^{2}$, Imam Susilo ${ }^{3}$, Junaidi Khotib ${ }^{2}$ \\ ${ }^{1}$ Master Program of Pharmaceutical Science, Faculty of Pharmacy, Universitas Airlangga, Indonesia \\ ${ }^{2}$ Department of Clinical Pharmacy, Faculty of Pharmacy, Universitas Airlangga, Indonesia \\ ${ }^{3}$ Department of Anatomic Pathology, Faculty of Medicine, Universitas Airlangga, Indonesia
}

\begin{abstract}
ABSTRAK
Rheumatoid arthritis (RA) adalah bentuk kronis peradangan persisten. Sementara itu, substansi P adalah neuropeptida yang paling terkait dalam inflamasi neurogenik dan hiperalgesia umumnya ditemukan dalam penyakit kronis. Substansi P bertindak sebagai pengikat neurokinin-1 reseptor. Penelitian ini dilakukan untuk mengevaluasi efek dari neurokinin-1 antagonis reseptor (CP-96345) pada model tikus induksi artritis, yang diinduksi oleh Complete Freund Adjuvant (CFA). Tujuannya adalah untuk melemahkan inflamasi neurogenik yang pada gilirannya akan meningkatkan waktu latency hiperalgesia respon, menurunkan ekspresi neurokinin1 reseptor, dan menghambat perkembangan RA dalam model tikus AIA. Tikus intra-articularly disuntik dengan CFA 1 jam setelah administrasi CP-96345 baik dengan 0,63 ug / gr; 1,25 ug / gr; atau 2,5 mg / gr juga intra articularly. Pengukuran Caliper dan uji hot-plate dilakukan pada hari 0, 3, 5, 7, 9, 11, dan hari 13. Ekspresi neurokinin-1 reseptor di jaringan sendi dievaluasi oleh imunohistokimia, dan RA kemajuan dalam jaringan sendi yang diamati hystopathologically. CP-96345 sebesar 2,5 ug / gr significantly meningkatkan latency dari hiperalgesia waktu respon pada tikus CFA diinduksi $(p=0,044)$ dan menurunkan neurokinin-1 ekspresi reseptor di jaringan sendi $(p=0,029)$ dibandingkan dengan CFA diinduksi tikus. Tidak ada perbedaan significant untuk pengukuran caliper dan kemajuan RA antara CFA incduced tikus dan kelompok perlakuan. Meyakinkan, CP-96345 meningkatkan latency waktu respon hiperalgesia dan mengurangi NK-1 ekspresi reseptor di tikus bersama tapi tidak bisa menghambat perkembangan RA. (FMI 2016;52:87-93)
\end{abstract}

Kata kunci: CP-96345, rheumatoid arthritis, hiperalgesia, neurokinin-1, CFA

\begin{abstract}
Rheumatoid arthritis (RA) is a chronic form of persistent inflammation. Meanwhile, Substance P is the most associated neuropeptide in neurogenic inflammation and hyperalgesia commonly found in chronic pain. Substance $P$ act by binding to neurokinin-1 receptor. The present study was conducted to evaluate the effect of neurokinin-1 receptor antagonist (CP-96,345) on Adjuvant Induced Arthritis rat model, induced by Complete Freund's Adjuvant (CFA). The objective is to attenuate neurogenic inflammation which in turn will increase the latency time of hyperalgesia response, decreases neurokinin-1 receptor expression, and inhibits the development of RA in AIA rat model. Rats were intra-articularly injected with CFA 1 hour after the administration of CP-96,345 either by $0.63 \mu \mathrm{g} / \mathrm{gr} ; 1.25 \mu \mathrm{g} / \mathrm{gr}$; or $2.5 \mu \mathrm{g} / \mathrm{gr}$ also intra-articularly. Caliper measurements and hot-plate test were performed on day $0,3,5,7,9,11$, and day 13. Expression of neurokinin-1 receptor in joint tissue were evaluated by immunohistochemistry, and RA progress in joint tissue were observed hystopathologically. CP-96,345 at $2.5 \mu \mathrm{g} / \mathrm{gr}$ significantly increases the latency of hyperalgesia response time on $C F A$ induced rats $(p=0.044)$ and decreased the neurokinin-1 receptor expression in joint tissue $(p=0.029)$ compared to CFA induced rats. There was no significant difference for caliper measurements and RA progress between CFA incduced rats and treated group. Conclusively, CP-96,345 increases the latency of hyperalgesia response time and decreases the NK-1 receptor expression in rat joint but could not inhibit RA progression. (FMI 2016;52:87-93)
\end{abstract}

Keywords: CP-96,345, rheumatoid arthritis, hyperalgesia, neurokinin-1, CFA

Correspondence: Junaidi Khotib, Department of Clinical Pharmacy, Faculty of Pharmacy, Universitas Airlangga, Indonesia, Dharmawangsa Dalam Surabaya 60286-Indonesia. e-mail address: Junaidi-k@ff.unair.ac.id, wirasasmita_y@ymail.com

\section{INTRODUCTION}

Chronic pain (neuropathic pain) occurs when there is trauma in the nervous system as seen in rheumatoid arthritis (RA) (Inoue et al 2013), which is a chronic form of inflammation (Vashist et al 2012, Aggarwal \&
Myles 2013, Emery 2011). The most common symptom of neurophatic pain includes spontaneus pain, hyperalgesia, and allodynia (Inoue et al 2013). Treatment with NSAID's in RA is not ideal because of its longterm side effect. DMARD's and TNF- $\alpha$ Inhibitors therapy now had become popular (Emery 2011). 
Even then, pain still become the main symptom that could not be controlled properly (Breedveld \& Kalden 2004, Lee \& Hasset 2011). This indicates there is another factor playing role in the development of chronic pain in RA (Lee \& Hasset 2011). Neurogenic inflammation had been repeatedly suggested to play important role in chronic inflammation (Richardson \& Vasko 2002, Johnson \& Bolay 2005, Ren \& Dubner 2010, Peterson et al 2013). Substance P is the most associated with neurogenic inflammation and hyperalgesia (Richardson \& Vasko 2002, Davis \& Perkins 1996, Bhatia et al 2009, Brain \& Keeble 2004). SP can be released when there is a repeated stimulation on the neurons (Geppeti et al 2006, Dickenson 1999) and act as a potent pro-inflammatory agent (O'Connor et al 2004) inducing inflammation pathway other than those that already exists. Therefore creating redundancy between neuro-immune interaction where the inflammation process is maintained and prolonged ( $\mathrm{O}^{\prime} \mathrm{Connor}$ et al 2004, Cases et al 2005, Reedquist \& Tak 2012, Austin \& Taylor 2010, Aloisi \& Bonifazi 2006). SP act by binding to neurokinin-1 (NK-1) receptor (Krause et al 1992). The tachykinins, through acting on NK-1 receptors have been long suspected to play a role in acute and neurogenic inflammation (Han et al 2002, Peterson et al 2013, Hallin et al 1992, Friess et al 2001) and have been well documented in tendons with chronic pain (Peterson et al 2013). Meanwhile, not many data available on how the role of NK-1 in the management of pain where SP is bound to be released (e.g in RA), instead of being injected to induce the hyperalgesia response (Davis \& Perkins 1996, Teodoro et al 2013). In this study, we explore the possibility of using NK-1 receptor antagonist as a local analgesic in the management of chronic pain associated with inflammation, and protecting the joint tissue from further damage.

\section{MATERIALS AND METHODS}

\section{Animals}

Animal used in the present study were 6 to 8 week-old male Wistar rats weighing 150-200 g. Rats were housed in single cages with $12 \mathrm{~h}$ light-dark cycles for 1 week before the experiments. Water and food were available and can be accessed freely. All experimental procedures were approved by Animal Care and Use Committee of Veterinary Medicine Faculty, Universitas Airlangga, Indonesia (Approval number; 434-KE).

\section{Animal Model}

To obtain rheumatoid arthritis model, rats were injected with $25 \mu 1$ of CFA (Sigma-Aldrich) solution into the tibiofemoral joint of the right hind leg under propofol anesthesia $(10 \mathrm{mg} / \mathrm{kg}$.i.v) using microsyringe with a 26 $\mathrm{G}$ needle (referred to as day 0). CFA solution were vortex-mixed before each injection. A control group was assigned and injected with salin with the same volume.

\section{Drug administration}

$1 \mathrm{~h}$ prior to CFA injection, the rats were anesthetized with i.v propofol $(10 \mathrm{mg} / \mathrm{kg})$ and NK-1 receptor antagonist CP-96,345 (Sigma-Aldrich) either $0.63 \mu \mathrm{g} / \mathrm{g}$; $1.25 \mu \mathrm{g} / \mathrm{g}$; or $2.5 \mu \mathrm{g} / \mathrm{g}$ were administered intra-articularly using microsyringe and a $30-\mathrm{G}$ needle. CP-96,345 were dissolved in solution of $40 \%$ DMSO and $60 \%$ salin. A control group was assigned with the injection of only the vehicle.

\section{Behavioral Examination}

Hyperalgesia response was tested on day 0 (before any treatment), and then on day 5, 7, 9, 11, and day 13 using hot-plate instrument (Ugo Basile) with $30 \mathrm{sec}$ cut off time. The 3rd day of examination point was skipped as the rats were left immobile due to the severe swelling on their joint. Rat were placed on the plate and nociceptive responses were observed either for paw licking, rearing, tapping, straightening or jumping off. The time needed for rat to initiate nociceptive responses were recorded as hyperalgesia latency time.

\section{Assesment of physiological parameters for inflammation}

Caliper measurements were conducted prior to any treatment on day 0 , and then on day $3,5,7,9,11$, and day 13 to detect any swelling of the tibiofemoral joint. The space between medial and lateral meniscus of the affected joint were measured with feret method using vernier caliper.

\section{Histological analysis}

On day 13th after the last observation, rats were anesthetized with i.v propofol $(10 \mathrm{mg} / \mathrm{kg})$ and then blood were drained transcardially. The tibiofemoral joint were dissected out and fixated in $4 \%$ paraformaldehyde at room temperature overnight. Tissue were then decalcified in $10 \%$ EDTA (Merck) solution (pH 7.4) for 4 weeks and cut into cross sections. The sections were stained with $1 \%$ hematoxylin (Merck) for $3 \mathrm{~min}$. Image from stained sections were captured with a CX 22 microscope equipped with digital camera (Olympus). 


\section{Immunohistochemistry analysis}

Prepared tissue sections were deparafinized by washing with xylol $3 \times 5 \mathrm{~min}$, and then by alcohol $5 \mathrm{~min}$ each of $100 \%, 95 \%$, and $80 \%$, and then lastly in PBS for $3 \times 5$ min. sections incubated in $10 \%$ of hydrogen peroxidase for $5 \mathrm{~min}$, and antigen retrieval were performed using ready-to use DIVA decloaking solution (Biocare Medical) and microwaved (domestic microwave) for $10 \mathrm{~min}$, all the while keeping the buffer solution level. Sections were incubated in primary antibody NK-1 receptor bs0064R (Bioss) overnight at $4{ }^{\circ} \mathrm{C}$ and then in secondary antibody simple strain rat mas PO (Bioss) for $30 \mathrm{~min}$ at room temperature. Chromogen were added using DAB solution for $20 \mathrm{~min}$ at room temperature and counterstained using hematoxylin-eosin solution for $5 \mathrm{~min}$. Tissue sections were rehydrated and ready for mounting. Image from stained sections were captured using a CX 22 microscope equipped with digital camera (Olympus).

\section{Statistical Analysis}

Values were expressed as means \pm SD. Effect of CP96,345 on hyperalgesia response and caliper measurements were analyzed by two-way analysis of variance (ANOVA) repeated measurements, followed by individual post hoc multiple comparisons (Tukey test). The expression of NK-1 receptor were counted using Allred scoring method, and the values were analyzed by non-parametric analysis (Kruskall-Wallis) followed by Mann-Whitney post hoc multiple compar-ison tests. Values of $p<0.05$ were considered to be statistically significant.

\section{RESULTS}

Time course of the mechanical hyperalgesia and caliper measurements on CFA induced rats

The latency time of hyperalgesia response on day 5 both CFA induced and control group were decreased compared to day 0 . On day 7 onward, control group values gradually reversed back reaching its initial latency time while the latency time on CFA induced group were continued to shorten. The values were analized on both groups at corresponding days by two way ANOVA repeated measure $(p=0.019)$ and the difference were seen to occur on day $9(p=0.022)$. CFA-induced group showed significant increase in the length of caliper measurements on day $3 \mathrm{rd}(\mathrm{p}=0.006)$ compared to control group. Although it is not significantly different on day $5,7,9$, and 11 , the values were constantly above the control group and peaked again on day 13th and was considered significanty different $(p=0.021)$.

\section{Effect of CP-96,345 on CFA induced rats}

The injection of CP-96,345 prior to the CFA injection apparently could not inhibit the swelling formed on day 3 . All treated group have increased caliper measurements as seen in CFA induced rats (Fig.1)

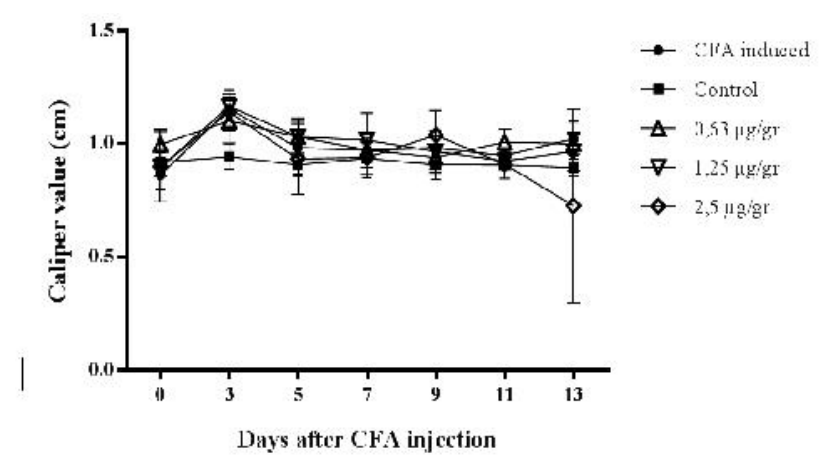

Fig.1 By two-way ANOVA-RM analysis, all CP-96,345 treatment groups were compared to control and CFA induced rats. There was no statistically different mean value observed $(p=0.052)$.

On the other hand, injection of CP-96,345 showed significant effect on increasing the latency time of hotplate test. All 3 of treated group have increased latency time compared to the CFA induced rats model group, showing dose dependent manner (Fig.2).

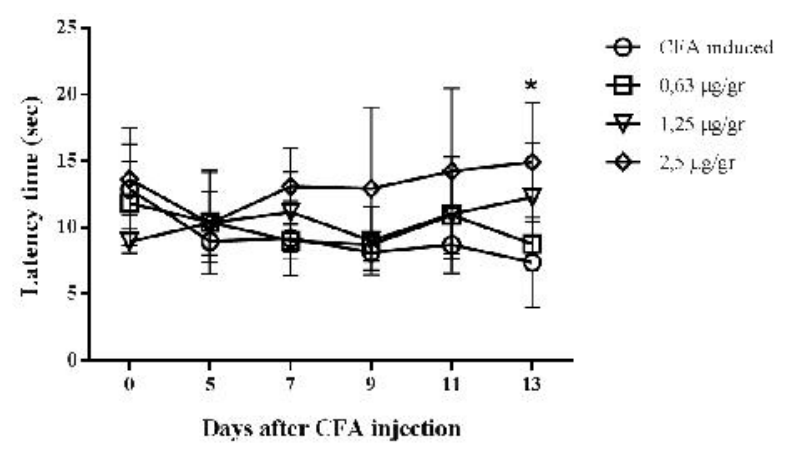

Fig. 2 Effect of CP-96,345 administration on CFA induced hyperalgesia response. By two-way ANOVA-RM analysis, there was statistically different mean value observed at $\mathrm{p}=0.029$. Dunnet's post hoc analysis for multiple comparison were then performed, and CP96,345 at $2.5 \mu \mathrm{g} / \mathrm{g}$ was considered statistically different compared to CFA induced rats $(\mathrm{p}=$ 0.022). Further Tukey's analysis revealed the difference occured on day 13 th $(p=0.044)$. 


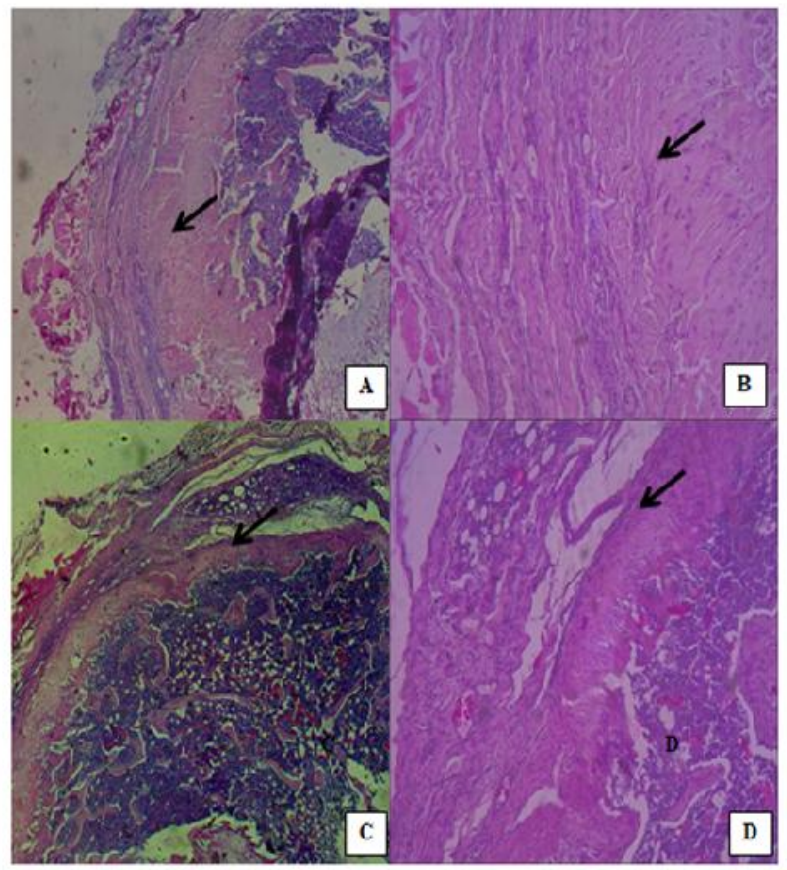

Fig. 3 H-E staining on joint tissue cross-sections. CFA induced rat (A) magnified 40x and (B) magnified 100x. Compared to control (C) magnified 40x and (D) magnified 100x. Hyperplasia of synovial lining can be seen in the joint of CFA induced rat, noted by the black arrow, where as the control group still have normal synovial lining. Under the synovial lining, cartilage erosion can also be observed, where as the control group cartilage remained compact.

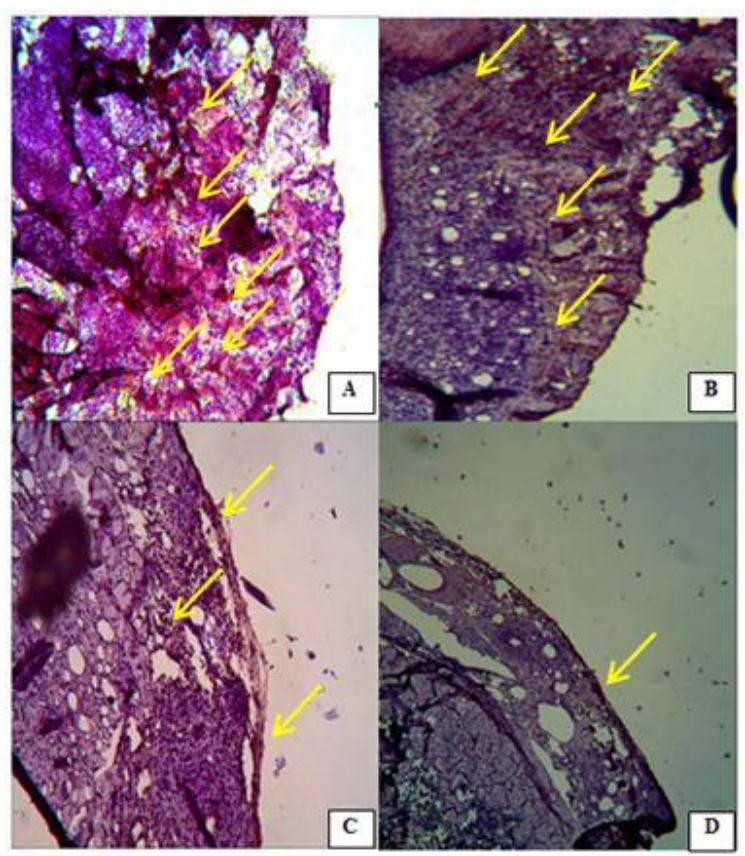

Fig. 4. NK-1 receptor Immunoreactivity (brown stain) on synovial membrane of CFA induced rat, noted by yellow arrows. (A), and treated rat with CP-96,345 either by $0.63 \mu \mathrm{g} / \mathrm{gr}$ (B); $1.25 \mu \mathrm{g} / \mathrm{gr}$; or $2.5 \mu \mathrm{g} / \mathrm{gr}$ (D). All magnified100x. 


\section{Hystological findings on the joint}

By hematoxylin-eosin staining, the joint tissue from rats group were examined under microscope. CFA induced rats showed RA characteristics (Fig.3) with visible proliferation, pannus formation, and hyperplasia of the synovial lining. CP-96,345 injection could not alter the progress of this joint destruction as all of treated group also showed the same RA characteristics (data not shown).

\section{Expression of NK-1 receptors in the joint}

All treatment group and CFA induced group showed NK-1 activity with different intensities by immunohistochemistry staining (Fig.4). The expressions were evaluated by Allred scoring method. The expression of NK-1 receptor also showed dose dependent manner of CP-96,345 injected. CFA induced rats showed high intensity of NK-1 receptor expression, and the treated group showed diminished intensity as CP-96,345 concentration gets higher.

\section{DISCUSSION}

On present study, we note the effect of NK-1 receptor antagonist on attenuating hyperalgesia response in CFA induced rat of RA model. Rheumatoid arthritis occurs after persistent joint inflammation that triggers edema, vascular remodelling and cellular infiltration. SP triggers inflammation condition by inducing cytokines and chemokines expressions such as macrophage inflammatory protein-1 $\alpha$ (MIP- $1 \alpha$ ) and monocyte chemotactic protein-1 (MCP-1) through NF-kb path-way. SP also increases neutrophil recruitment and adhesion process by triggering the upregulation of chemokines receptors (Bhatia et al 2012).

Substance $\mathrm{P}$ act by binding to neurokinin-1 (NK-1) receptor and leads to longer depolarization time by activating $\mathrm{K}+$ current or by increasing $\mathrm{Na}+$ or $\mathrm{Ca}+$ currents. NK-1 antagonis can block this spinal response initiation, and reduces further signaling pathway triggered by N-methyl-D-aspartate (NMDA) receptors. As have been understood, activation of alpha-amino-3hydroxy-5-methyl-isoxazole (AMPA) receptors is associated with acute inflammation response, while NMDA receptors were associated with repeated stimulation of $\mathrm{C}$ fiber. Thus amplifying the neurons responses, prolonging the response and believed to have caused hyperalgesia (Dickenson 1999, Gerhardt \& Schmidtko 2011).

To confirm the RA model in rat, caliper measurements were conducted to asses the inflammation on affected joint. As expected, on day 3 the swelling occured on CFA induced rat $(p=0.006)$ compared to control. The adaptif immune response occur on day 3-7 when the effector cells T-helper limphocyte recruits more macrophage to eliminate phagocytozed microbes. In this process, the cytokines were also released and further activates yet macrophages, activates, proliferates, and differentiate $\mathrm{T}$ and $\mathrm{B}$ lymphocytes, that leads to inflammation (Abbas et al 2007). Consequently, the latency time for hyperalgesia response on CFA induced rats where shorter than the control $(p=0.019)$. While this can be acute inflammation phase, the expression of NK-1 receptors in the joint suggest that SP were already involved and there has been repeated stimulation of nerve endings by previous cytokines. Thus the inflammation is no longer in acute phase but leading to its chronic phase.

CP-96,345 could not inhibit swelling on the CFA induced rat joint. This result is in line with previous study (Han et al 2002). On the other hand the statistical anylisis mentioned previously, has a very narrow result to achieve before it becomes significant. Added to this, the effect of CP-96,345 observed were dose dependent manner, as seen in previous study (Lembeck et al 1992) the higher the dose, the more significant the effect. Thus there was a possibility that the dose was not enough, as the concentration applied in present study was the lowest working concentration of CP-96,345 for neurogenic inflammation (Bhatia et al 2006, Lembeck et al 1992, Pothoulakis et al 1994, Snider et al 1991, Nessler et al 2006).

Immunohistochemical staining revealed NK-1 receptors expression present on both control and CFA induced rats, only with higher intensity on CFA induced rats. This could mean that NK-1 receptors is also expressed even at basal condition. Although, we could not ignore the possibility that the NK-1 receptors expression on normal rats were the result of repeated stimulation of heat stimulus during hot-plate test. Histological findings confirmed there was proliferation and hypertrophy on synovial lining in the joint of CFA indiced rats compared to that of control's. Unfortunately, CP-96,345 could not alter the joint destruction progress, as the histology observation revealed the same RA characteristics found in all of treatment groups.

\section{CONCLUSION}

Taken together, present study provides evidence on the involvement of local NK-1 receptor in the signaling pathway leading acute inflammation phase into the chronic state of rheumatoid arthritis and the possibility of using NK-1 antagonist as local therapy in chronic 
pain associated with rheumatoid arthritis by attenuating hyperalgesia response.

\section{REFERENCES}

Abbas AK, Lichtman AH, Pillai S (2007). Cellular and Molecular Immunology, Philadelphia, Saunders Elsevier, p 5-12

Aggarwal A and Myles A (2013). Inflammatory cascades in autoimmune disease. In: Roy S, Bagchi D, Raychaudhuri SP (eds). Chronic Inflammation, Molecular Pathophysiology, Nutritional and Therapeutic Interventions, Florida, CRC Press, p 213220

Aloisi AM and Bonifazi M (2006). Sex hormones, central nervous system and pain. Hormones and Behavior 50, 1-7

Austin PJ and Taylor GM (2010). The neuro-immune balance in neuropathic pain: involment of inflammatory immune cells, immune-like glial cells and cytokines. Journal of Neuroimmunology 229, 2650

Bhatia M and Lau HY (2006). The effect of CP96,345 on the expression of tachykinins and neurokinins receptors in acute pancreatitis. Journal of Pathology 208, 364-371

Bhatia M, Moochhala S, Koh YH (2012). Activation of neurokinin-1 receptors up-regulates substance $\mathrm{P}$ and neurokinin-1 receptor expression in murine pancreatic acinar cells. Journal of Molecular Medicine 16, 15821592

Bhatia M, Tamizhselvi R, Ramnath RD, Sun J (2009). Role of protein kinase $\mathrm{C}$ and phosponoisitide 3kinase-Akt in substance $\mathrm{P}$-induced proinflammatory pathways in mouse machrophages. The Journal of The Federation of American Societies for Experimental Biology 23, 997-1010

Brain SD and Keeble JE (2004). A role for substance P in arthritis. Neuroscience Letters 361, 176-179

Breedveld FC and Kalden JR (2004). Appropriate and effective management of rheumatoid arthritis. Annals of Rheumatic Disease 63, 627-633

Cases RP, Sanz NG, Palao CM, Montiel AF (2005). Functional aspects and mechanisms of TRPV1 involment in neurogenic inflammation that leads to thermal hyperalgesia. European Journal of Physiology 451, 151-159

Davis AJ and Perkins MN (1996). Substance P and capsaicin-induced mechanical hyperalgesia in the rat knee joint; the involment of bradykinin B1 and B2 receptors. British Journal of Pharmacology 118, 22062212

Dickenson A (1999). The roles of spinal receptors in nociceptive responses. In: Brain SD and Moore PK (eds). Pain and Neurogenic Inflammation, New York, Springer, p 23-38

Emery P (2011). Pocket Reference to Early Rheumatoid Arthritis, London, Springer Healtcare Ltd, p 3-51

Geppeti P, Materazzi S, Nicoletti P, Trevisani M (2006). In vivo models of neurogenic inflammation. In: Stevenson CS, Marshall LA, Morgan DW (eds). In Vivo Models of Inflammation, Vol 1, Switzerland, Birkhäuser Basel, p 121-135

Gerhardt WK abd Schmidtko A (2011). A novel signaling pathway that modulates inflammatory pain. The Journal of Neuroscience 3, 798-800

Hong SK, Han JS, Min SS, Hwang JM, Kim YI, Na HS, Yoon YW, Han HC (2002). Local neurokinin-1 receptor in the knee joint contributes to the induction, but not maintenance, of arthritic pain in the rat. Neuroscience Letters 322, 21-24

Johnson K and Bolay H (2005). Neurogenic inflammatory mechanisms. In: Olesen J, Tfelt-Hansen P, Welch K, Goadsby PJ, Ramadan N. Headaches, Philadelphia, Lippincot Williams \& Wilkins, p 311

Krause JE, Takeda Y, Hershey AD (1992). Structure, functions, and mechanisms of substance $\mathrm{P}$ receptor action. Journal of Investigative Dermatology 98, 2S$7 \mathrm{~S}$

Lee YC and Hasset AL (2011). Pain in rheumatoid arthritis. Available from http://www.therheumatologist.org/article/pain-in-rheumatoidarthritis/. Accessed 10 November, 2014

Lembeck F, Donnerer J, Tsuchiya M, Nagahisa A (1992). The non-peptide tachykinin antagonist, CP96,345 is a potents inhibitor of neurogenic inflammation. British Journal of Pharmacology 105, 527-530

Nessler S, Stadelmann C, Bittner A, Schlegel K, Gronen F, Brueck W, Hemmer B, Sommer N (2006). Suppression of autoimmune encephalomyelitis by a neurokinin-1 receptor antagonist - a putative role for substance $P$ in CNS inflammation. Journal of Neuroimmunology 179, 1-8

O'Connor TM, O'Connell J, O'Brien DI, Goode T, Bredin CP, Shanahan F (2004). The role of substance $\mathrm{p}$ in inflammatory disease. Journal of Cellular Physiology 201, 167-180

Peterson M, Svärdsudd K, Appel L, Engler H, Aarnio M, Gordh T, Långström B, Sörensen J (2013). PETscan shows peripherally increased neurokinin 1 receptor availability in chronic tennis elbow: visualizing neurogenic inflammation? PloS ONE 8, e75859

Pothoulakis C, Castagliuolo I, Lamont JT, Jaffer A, O'Keane JC, Snider RM, Leeman SE (1994). CP96,345, a substance $P$ antagonist inhibits rat intestinal responses to clostridium difficile toxin A but not cholera toxin. Proceedings of the National Academy of Sciences 91, 947-951 
Reedquist KA and Tak PP (2012). Signal transduction pathways in chronic inflammatory autoimmune disease: small GTPases. The Open Rheumatology Journal 6, 259-272

Ren K and Dubner R (2010). Interactions between the immune and nervous systems in pain. Nature Medicine 16, 1267-1276

Richardson JD and Vasko MR (2002). Cellular mechanisms of neurogenic inflammation. The Journal of Pharmacology and Experimental Therapeutics 302, 839-845

Shrikhande SV, Friess H, di Mola FF, Tempia-Caliera A, Garcia JRC, Zhu Z, Zimmermann A, Büchler MW (2001). NK-1 receptor gene expression is related to pain in chronic pancreatitis. Pain 91, 209-217

Snider RM, Longo KP, Drozda SE, Lowe JA, Leeman SE (1991). Effect of CP-96,345 a nonpeptide substance $\mathrm{P}$ receptor antagonist on salivation in rats. Proceedings of National Academy of Sciences 88, 10042-10044
Teodoro FC, TroncoJr MF, Zampronio AR, Martini AC, Rae GA, Chichorro JG (2013). Peripheral substance P and neurokinin-1 receptors have a role in inflmammatory and neurophatic orofacial pain models. Neuropeptides 47, 199-206

Tsuda M, Masuda T, Tozaki-Saitoh H, Inoue K (2013). P2X4 receptors and neuropathic pain. Frontiers in Cellular Neuroscience 7, 167-172

Vashist H, Gupta A, Jindal A, Jalhan S (2012). animal models for arhtritis-a review. International Journal of recent Advances in Pharmaceutical Research 2, 20-25

Xu XJ, Dalsgaard CJ, Maggi CA, Wiesenfeld-Hallin Z (1992). NK-1, but not NK-2, tachykinin receptors mediate plasma extravasation induced by antidromic C-fiber stimulation in rat hindpaw: demonstrated with the NK-1 antagonist CP-96,345 and the NK-2 antagonist men 10207. Neuroscience Letters 139, 249252 